\title{
ANALISIS RISIKO TEKNOLOGI INFORMASI MENGGUNAKAN ISO 31000 PADA APLIKASI ITOP
}

\author{
Aprilia Rahmawati ${ }^{1}$, Agustinus Fritz Wijaya ${ }^{2}$ \\ ${ }^{1,2}$ Fakultas Teknologi Informasi, Universitas Kristen Satya Wacana, Salatiga
}

\section{Article Info:}

Dikirim: 15 Maret 2019

Direvisi: 04 April 2019

Diterima: 04 Mei 2019

Tersedia Online: 29 Juni 2019

Penulis Korespondensi:

Aprilia Rahmawati

Fakultas Teknologi Informasi,

Universitas Kristen Satya Wacana,

Salatiga, Indonesia

Email:

aprilia_rahmawati@outlook.co.id

\begin{abstract}
Abstrak: Aplikasi IT Operation Support (iTop) merupakan support system yang membantu PT. ABCD menerima customer incident. Keberadaan aplikasi iTop ini membantu perusahaan untuk mengetahui kualitas layanan kepada customer. Kualitas layanan customer ditentukkan oleh aplikasi ini sehingga dibutuhkan analisis risiko untuk mencegah risiko yang mungkin terjadi. Analisis risiko dengan menggunakan ISO 31000 pada PT. ABCD diharapkan dapat meminimalisir kemungkinan-kemungkinan risiko di sekitar aplikasi iTop. Hasil analisis risiko dengan ISO 31000 berupa dokumentasi kemungkinan risiko yang ada di sekitar aplikasi iTop, prioritas risiko dari tiap kemungkinan risiko yang telah diidentifikasi serta penanganan dari kemungkinan-kemungkinan risiko yang ada. Sehingga hasil analisis risiko ini dapat digunakan untuk membantu perusahaan mencegah, meminimalisir risiko serta memperlakukan risiko tersebut sesuai prioritasnya sebelum kemungkinan risiko-risiko tersebut menghambat kinerja perusahaan.
\end{abstract}

Kata kunci: manajemen analisis risiko; ISO 31000; IT operation support (iTop).

\begin{abstract}
Top application is a support system that help PT. ABCD to receive customer incident. The exixtence of iTop application is help company to know their service quality to customer. Their customer service quality decided by this application that needed risk analysis to prevent possible risk that maybe happened. A risk analysis using ISO 31000 to PT. ABCD expected can minimize the emergence of the possible risk. The result of risk analysis using ISO 31000 is documentation of possible risk around iTop application, risk priority of the possible risk that already identified and handle the existing possible risk. The results of risk analysis can used to help company prevent, minimize risk and treat the risk by thir priority before the possible risk hamper company performance.
\end{abstract}

Keywords: risk analysis management; ISO 31000; IT operation suport (iTop). 


\section{PENDAHULUAN}

PT. ABCD merupakan perusahaan yang bergerak di bidang IT yang melayani jasa Total IT Managed Service di Indonesia. Dalam memberikan layanan terkelola bagi kliennya PT. ABCD memiliki 7 pilar utama yaitu product solution, field services, operation command center, data center, security services, developer, dan contact center. Layanan terkelola yang diberikan bertujuan agar klien dapat berfokus pada bisnis perusahaan mereka tanpa mengkhawatirkan permasalahan IT di dalam perusahaan.

Namun permasalahan IT dapat terjadi dimana saja dan kapan saja. Saat terjadi permasalahan IT pada klien PT. ABCD dibutuhkan penanganan segera dari staff operational IT untuk memperbaiki insiden yang terjadi. Untuk menerima laporan mengenai permasalahan IT yang dihadapi oleh klien, PT. ABCD menggunakan aplikasi iTop.

iTop adalah aplikasi open source CMDB (Configuration Management Data Base) yang berfungsi untuk menghubungkan proses operational IT PT. ABCD. Berbagai fitur yang ada di aplikasi iTop yaitu incident and user request management, transparent SLA, problem management, customizable CMDB dan chat messenger. Aplikasi iTop membantu perusahaan untuk mendapatkan laporan mengenai kualitas layanan yang diberikan oleh perusahaan kepada klien. Aplikasi iTop sangat penting bagi staff operational IT dalam membuat laporan kepada perusahaan.

Setiap aplikasi pasti memiliki berbagai kemungkinan risiko yang dapat menggangu sehingga aplikasi tidak dapat berjalan optimal. Kemungkinan risiko yang ada dapat muncul dari berbagai faktor baik dari internal atau eksternal aplikasi tersebut. Tidak terkecuali aplikasi iTop, apikasi tersebut juga dapat mengalami kemungkinankemungkinan risiko yang muncul di sekitarnya. Berdasarkan permasalahan tersebut, maka dibutuhkan penelitian untuk mendokumentasikan berbagai macam kemungkinan risiko serta prioritas risiko-risiko tersebut terhadap perusahaan. Sehingga dengan tujuan tersebut dapat dilakukan analisis manajemen risiko menggunakan ISO 31000.

Penelitian manajemen risiko di Bandara Soekarno Hatta mengacu pada ISO 31000 dilakukan pada tahun 2013 oleh Terry George Abisa. Analisis risiko yang dilakukan meliputi 3 tahapan ISO 31000. Hasil dari penelitian tersebut menunjukkan adanya 7 peristiwa risiko yang berpotensi bahaya dan perancangan sistem pengendalian risiko yang ada sudah dibuat dengan baik. [1]

Analisis risiko menggunakan ISO 31000 juga dilakukan pada sistem i-Gracias di Universitas Telkom oleh Andi Novia Rilyani pada tahun 2015. Analisis risiko pada penelitian berfokus pada hardware dan infrastruktur jaringan sistem i-Gracias. Dari hasil penelitian didapatkan dokumentasi tingkatan risiko pada sistem i-Gracias serta rekomendasi untuk menangulangi risiko yang sudah teridentifikasi. [2]

Pada tahun 2107, Stefan Agustinus melakukan analisis risiko teknologi informasi menggunakan ISO 31000 pada program Human Resources Management System (HRMS). Analisis risiko dilakukan degan tujuan mendokumentasikan kemungkinan risiko di sekitar program HRMS dan memberikan perlakukan risiko untuk meminimalisir kemungkinan risiko tersebut. Dari hasil penelitian ditemukan 26 kemungkinan risiko program HRMS beserta tingkatan level risiko yang ada. [3]

Berdasarkan penelitian-penelitian tersebut dapat dilihat bahwa terdapat hubungan dengan penelitian yang akan dilakukan penulis yaitu analisis risiko menggunakan ISO 31000 yang bertujuan untuk mengidentifikasi kemungkinan risiko yang muncul, dampak dari risiko tersebut, level risiko, dan perlakuan risiko terhadap kemungkinan-kemungkinan risiko yang ada. Peneitian yang akan penulis lakukan adalah analisis risiko aplikasi iTop pada PT. ABCD. Yang mampu menghasilkan dokumentasi kemungkinan risiko yang dapat muncul beserta level dampak risiko tersebut terhadap aplikasi iTop serta rekomendasi terhadap perlakukan risiko yang dapat dilakukan untuk meminimalisir risiko yang ada.

Manajemen risiko mencakup proses identifikasi, pengukuran risiko dan membuat strategi untuk pengelolaan sumber daya yang ada, Tujuan dari manajaemen risiko adalah mengelola risiko-risko yang ada sehingga perusahaan mendapatkan hasil yang optimal. [4]

Beberapa prinsip dasar dalam manajemen risiko untuk diterapkan di dalam binis, yaitu :

a. Memahami business goal.

b. Mengidentifikasi hal yang menghambat tercapainya business goal.

c. Menentukan pengendalian untuk meminimalisir risiko-risiko yang ada.

Perusahaan perlu melakukan analisis risiko terhadap aset-aset teknologi informasi dikarenakan risiko dapat muncul dimana saja dan kapan saja, jika tidak dianalisa sebelumnya maka tidak dapat dilakukan pengendalian terhadap risiko yang ada dan dapat menggangu kinerja perusahaan. Sehingga dengan penelitian yang akan penulis lakukan dapat membantu perusahaan menangulangi risiko terhadap aset-aset aplikasi iTop. Serta dengan adanya dokumentasi risiko serta rekomendasi perlakukan risiko tersebut dapat menjadi acuan perusahaan dalam memperlakukan risiko sebelum risiko-risiko tersebut menghambat kinerja perusahaan. 


\section{METODOLOGI PENELITIAN}

International Organization for Standardization (ISO) 31000 seperti yang ditunjukkan pada gambar 1, merupakan standar yang disusun dengan tujuan memberikan prinsip dan pedoman manajemen risiko secara universal. Di dalam International Organization for Standardization (ISO 31000:2009) terdapat 2 tahapan dalam proses manajemen risiko. Tahapan pertama adalah risk assesment yang merupakan proses menentukan risiko yang berpotensi menanggu perusahaan mmencapai business goal. Di dalam tahapan risk assessment terdapat 3 proses yaitu risk identification, risk analysis, dan risk evaluation. Risk identification yaitu proses mengidentifikasi kemungkinan-kemungkinan risiko yang dapat menghambat perusahaan, risk analyst yaitu proses menentukan risiko yang berpotensi menghambat perusahaan mencapai business goal, risk evaluation yaitu proses evaluasi setiap kemungkinan risiko berdasarkan tingkat kegawatan berdasarkan kriteria yang telah dibuat. Tahapan selanjutnya yaitu risk treatment dimana peneliti melakukan penyeleksian terhadap kemungkinankemungkinan risiko sebelumnya. Sehingga kemungkinan-kemungkinan risiko dan dampak risiko dapat bertambah atau berkurang. [5]

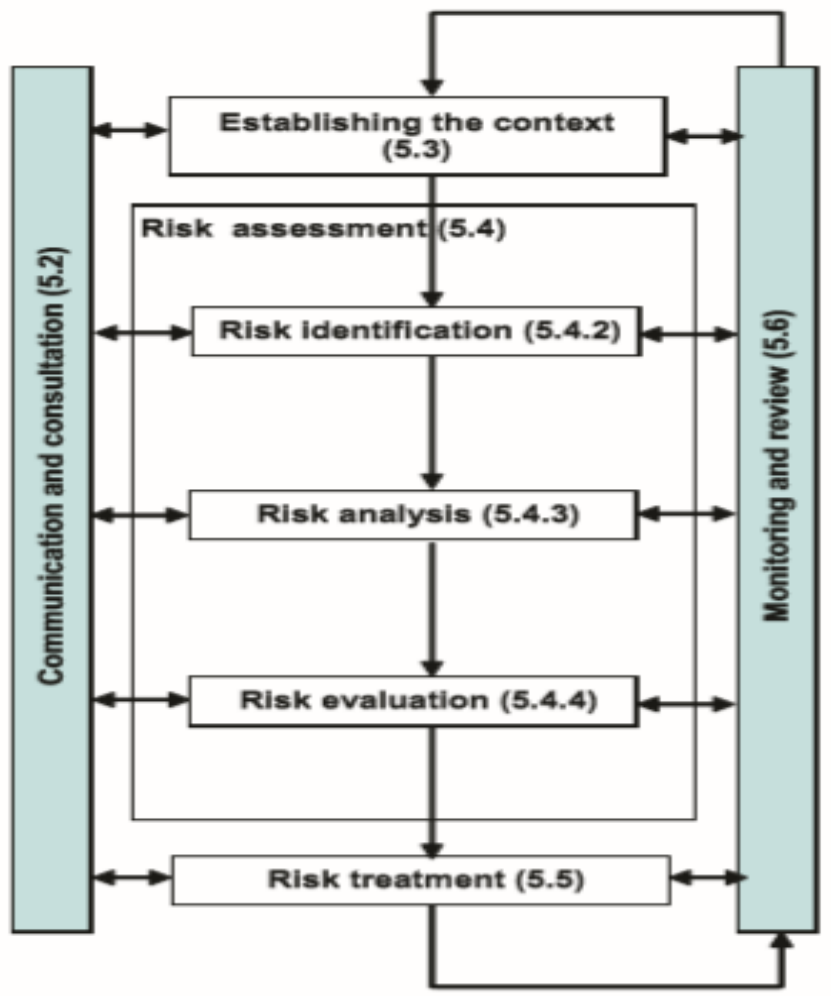

Gambar 1. Risk Management - Principles and Guidelines

Metode yang akan penulis gunakan dalam penelitian ini adalah metode case study research.. Metode ini berfokus pada satu kasus serta sample yang digunakan berupa individu atau kelompok. Sehingga dengan metode ini penulis dapat mengumpulkan data lebih pada objek yang diteliti untuk menjawab permaslahan yang ada. Data pada penelitian ini berupa data primer, dimana sumber data dikumpulkan dalam bentuk dokumen yang sudah divalidasi dan diverifikasi oleh narasumber. Sumber data yang berasal dari tesis atau disertasi tidak dapat digunakan karena termasuk data tertier. [6]

Teknik pengumpulan data berupa wawancara. Penulis melakukan wawancara dengan IT Operation Support \& Biz Deputy Head dari PT. ABCD sebagai sumber internal. Sebagai narasumber beliau memiliki kompetensi berupa pengetahuan mengenai ISO 20000 dan mempunyai sertifikat ITIL (minimal foundation).

\section{HASIL DAN PEMBAHASAN}

\subsection{Risk Assesment}

Tahap risk assessment atau penilaian risiko merupakan tahap pertama yang dilakukan sesuai dengan pedoman analisis manajemen risiko ISO 31000. Dimana pada tahap ini akan terdapat 3 proses yang dilakukan yaitu risk identification, risk analysis, dan risk evaluation. Ketiga proses tersebut harus dilalui untuk ke tahap yang selanjutnya.

\subsubsection{Identifikasi Risiko}

Proses pertama dalam tahap risk assessment adalah proses risk identification atau identifikasi aset terkait aplikasi iTop dilakukan melalui proses wawancara dengan IT Operation Support \& Biz Deputy Head dari PT. ABCD. Pada tahap ini dilakukan identifikasi aset dari data, software hingga hardware yang berakaitan dengan aplikasi iTop. 
Tabel 1. Identifikasi aset iTop

\begin{tabular}{ll}
\hline \multicolumn{1}{c}{ Komponen Sisitem Informasi } & \multicolumn{1}{c}{ Aset iTop } \\
\hline Data & Data User Client, Data Aset \\
Software & IT Operational Portal (iTop) \\
Hardware & Personal Computer (PC), Server Database, Server Web Service \\
\hline
\end{tabular}

Setelah dilakukan identifiksi aset dari data, software hingga hardware yang berkaitan dengan aplikasi iTop. Selanjutnya adalah mengidentifikasi kemungkinan-kemungkinan risiko yang terkait dengan aset aplikasi iTop yang dapat muncul dari berbagai faktor seperti alam/lingkungan, manusia, sistem dan infrastruktur. Serta tidak lupa diberikan identitas untuk setiap kemungkinan risiko yang ditemukan.

Tabel 2. Identifikasi kemungkinan risiko

\begin{tabular}{cll}
\hline Faktor & ID & \multicolumn{1}{c}{ Kemungkinan Risiko } \\
\hline \multirow{4}{*}{ Alam / Lingkungan } & R01 & Banjir \\
& R02 & Gempa bumi \\
& R03 & Kebakaran \\
& R04 & Petir \\
& R05 & Pencurian perangkat/data \\
& R06 & Human Error \\
& R07 & Informasi diakses oleh pihak yang tidak berwenang \\
& R08 & Data dan informasi tidak sesuai fakta \\
& R09 & Kerusakan akibat ulah manusia (cybercrime dan vandalism) \\
& R10 & Server Down \\
R11 & Data corrupt \\
& R12 & Backup failure \\
& R13 & Web service mati secara tiba-tiba \\
& R14 & Hacking terhadap jaringan \\
R15 & Memori penuh \\
R16 & Koneksi jaringan terputus \\
& R17 & Kerusakan hardware \\
& R18 & Overheat \\
& R19 & Overload \\
R20 & Kurang baiknya kualitas jaringan \\
R21 & Listrik padam \\
\hline
\end{tabular}

Dari hasil proses identifikasi risiko ditemukan terdapat 21 kemungkinan risiko yang berasal dari faktor alam/lingkungan, manusia, sistem dan infrastruktur yang berpotensi mempengaruhi perusahaan. Kemudian kemungkinan-kemungkinan risiko yang telah teridentifikasi tersebut diidentifikasi dampaknya terhadap perusahaan. Sehingga di dalam proses ini dampak dari setiap kemungkinan risiko yang ada dapat teridentifikasi.

Tabel 3. Identifikasi dampak risiko

\begin{tabular}{|c|c|c|}
\hline$I D$ & Kemungkinan Risiko & Dampak \\
\hline R01 & Banjir & Terhambatnya aktivitas bisnis perusahaan. \\
\hline $\mathrm{R} 02$ & Gempa bumi & $\begin{array}{l}\text { Terjadi kerusakan infrastruktur dan jalannya } \\
\text { perusahaan terhenti. }\end{array}$ \\
\hline $\mathrm{R} 03$ & Kebakaran & $\begin{array}{l}\text { Terjadi kerusakan infrastruktur dan jalannya } \\
\text { perusahaan terhenti. }\end{array}$ \\
\hline R04 & Petir & Terjadi kerusakan infrastruktur. \\
\hline R05 & Pencurian perangkat/data & Kerugian finansial/ informasi data perusahaan. \\
\hline R06 & Human Error & User request tertunda. \\
\hline $\mathrm{R} 07$ & $\begin{array}{l}\text { Informasi diakses oleh pihak yang tidak } \\
\text { berwenang }\end{array}$ & $\begin{array}{l}\text { Tidak mempengaruhi perusahaan karena data iTop } \\
\text { berupa customer incident. }\end{array}$ \\
\hline R08 & Data dan informasi tidak sesuai fakta & Laporan insiden customer tidak valid. \\
\hline R09 & $\begin{array}{l}\text { Kerusakan akibat ulah manusia } \\
\text { (cybercrime dan vandalism) }\end{array}$ & Kerugian finansial/ informasi data perusahaan. \\
\hline $\mathrm{R} 10$ & Server down & Tidak dapat melakukan akses ke iTop dan database. \\
\hline R11 & Data corrupt & $\begin{array}{l}\text { Perusahaan tidak dapat menerima laporan yang valid } \\
\text { mengenai kualitas layanan kepada customer. }\end{array}$ \\
\hline $\mathrm{R} 12$ & $B a c$ & Data laporan insiden customer tidak lengkap. \\
\hline R13 & Web service mati secara tiba-tiba & $\begin{array}{l}\text { Customer tidak dapat mengakses iTop dan perusahaan } \\
\text { tidak dapat menerima laporan insiden customer. }\end{array}$ \\
\hline R14 & Hacking terhadap jaringan & $\begin{array}{l}\text { Pencurian data-data perusahaan dan aktivitas } \\
\text { penerimaan insiden customer terganggu. }\end{array}$ \\
\hline R15 & & Insiden customer yang baru gagal ditampung. \\
\hline R16 & Koneksi jaringa & agal melakukan al \\
\hline
\end{tabular}


Jurnal SITECH, Vol 2, No 1, Juni 2019

$P-I S S N$ : 2615-8531, E-ISSN : 2622-2973

\begin{tabular}{|c|c|c|}
\hline$I D$ & Kemungkinan Risiko & Dampak \\
\hline R17 & Kerusakan hardware & $\begin{array}{l}\text { Aktivitas perusahaan terhambat karena harus setup } \\
\text { data ke hardware yang baru. }\end{array}$ \\
\hline $\mathrm{R} 18$ & Overheat & $\begin{array}{l}\text { Kinerja hardware tidak maksimal dan hardware dapat } \\
\text { mengalami kerusakan jika menanggung suhu yang } \\
\text { panas terus-menerus. }\end{array}$ \\
\hline R19 & Overload & $\begin{array}{l}\text { Log database dan log temp database penuh. } \\
\text { Terjadinya bottleneck. }\end{array}$ \\
\hline $\mathrm{R} 20$ & Kurang baiknya kualitas jaringan & Akses ke iTop terhambat. \\
\hline $\mathrm{R} 21$ & Listrik padam & $\begin{array}{l}\text { Aktivitas perusahaan tidak tergangu karena memiliki } \\
\text { genset }\end{array}$ \\
\hline
\end{tabular}

\subsubsection{Risk Analysis}

Setelah kemungkinan- kemungkinan risiko beserta dampaknya telah teridentifikasi, langkah selanjutnya adalah proses analisis risiko. Pada proses ini terdapat tabel kriteria likelihood dan tabel kriteria impact yang digunakan sebagai acuan untuk proses analisis risiko. Tabel 4 merupakan tabel kriteria likelihood atau nilai kemungkinan yang telah ditentukan. Dalam penilaiannya likelihood dibedakan di dalam 5 kriteria yang dibedakan melalui seberapa banyak kemungkinan risiko tersebut dapat terjadi dalam kurun waktu tertentu.

Tabel 4. Kriteria likelihood

\begin{tabular}{|c|c|c|c|}
\hline \multicolumn{2}{|c|}{ Likelihood } & \multirow[b]{2}{*}{ Keterangan } & \multirow[b]{2}{*}{ Frekuensi kejadian } \\
\hline Nilai & Kriteria & & \\
\hline 1 & Rare & Risiko tersebut hampir tidak pernah terjadi & $>2$ tahun \\
\hline 2 & Unlikely & Risiko tersebut jarang terjadi & $1-2$ tahun \\
\hline 3 & Possible & Risiko tersebut kadang terjadi & $7-12$ bulan \\
\hline 4 & Likely & Risiko tersebut sering terjadi & $4-6$ bulan \\
\hline 5 & Certain & Risiko tersebut pasti terjadi & $1-3$ bulan \\
\hline
\end{tabular}

Tabel 5 merupakan tabel nilai impact atau dampak jika kemungkinan-kemungkinan risiko tersebut terjadi di perusahaan. Di dalam penilaiannya terdapat 5 kriteria dampak yang mungkin terjadi. Dari kelima kriteria tersebut dibedakan dari dampak yang tidak berpengaruh hingga dampak yang paling mempengaruhi kinerja perusahaan. Dari setiap dampak kemungkinan risiko yang telah diidentifikasi akan dimasukan satu per satu di dalam nilai impact yang telah ditentukan.

Tabel 5. Kriteria impact

\begin{tabular}{|c|c|c|}
\hline \multicolumn{2}{|c|}{ Impact } & \multirow[b]{2}{*}{ Keterangan } \\
\hline Nilai & Kriteria & \\
\hline 1 & Insignificant & Tidak mengganggu aktivitas perusahaan. \\
\hline 2 & Minor & Aktivitas perusahaan sedikit terhambat namun aktivitas inti perusahaan tidak terganggu. \\
\hline 3 & Moderate & $\begin{array}{l}\text { Menyebabkan ganguan pada proses bisnis sehingga sebagian jalannya aktivitas perusahaan } \\
\text { terhambat. }\end{array}$ \\
\hline 4 & Major & Menghambat hampir seluruh aktivitas perusahaan. \\
\hline 5 & Catastrophic & Aktivitas perusahaan berhenti karena proses bisnis mengalami gangguan total. \\
\hline
\end{tabular}

Setelah nilai kemungkinan dan dampak ditentukan, langkah selanjutnya adalah melakukan penilaian satu per satu terhadap kemungkinan risiko yang ada. Dari 21 kemungkinan risiko yang ada ditentukn satu per satu nilai likelihood dan nilai impact berdasarkan acuan tabel yang dibuat sebelumnya yang dapat dilihat detailnya pada tabel 6.

Tabel 6. Penilaian kemungkinan risiko dengan likelihood dan impact

\begin{tabular}{|c|c|c|c|}
\hline ID & Kemungkinan Risiko & Likelihood & Impact \\
\hline R01 & Banjir & 1 & 3 \\
\hline $\mathrm{R} 02$ & Gempa bumi & 1 & 5 \\
\hline R03 & Kebakaran & 1 & 5 \\
\hline R04 & Petir & 1 & 3 \\
\hline R05 & Pencurian perangkat/data & 2 & 2 \\
\hline R06 & Human Error & 3 & 2 \\
\hline R07 & Informasi diakses oleh pihak yang tidak berwenang & 2 & 1 \\
\hline R08 & Data dan informasi tidak sesuai fakta & 3 & 2 \\
\hline R09 & Kerusakan akibat ulah manusia (cybercrime dan vandalism) & 1 & 2 \\
\hline $\mathrm{R} 10$ & Server Down & 3 & 2 \\
\hline $\mathrm{R} 11$ & Data corrupt & 2 & 2 \\
\hline $\mathrm{R} 12$ & Backup failure & 2 & 2 \\
\hline $\mathrm{R} 13$ & Web service mati secara tiba-tiba & 2 & 2 \\
\hline R14 & Hacking terhadap jaringan & 1 & 3 \\
\hline $\mathrm{R} 15$ & Memori penuh & 1 & 2 \\
\hline $\mathrm{R} 16$ & Koneksi jaringan terputus & 3 & 4 \\
\hline
\end{tabular}




\begin{tabular}{|c|c|c|c|}
\hline$I D$ & Kemungkinan Risiko & Likelihood & Impact \\
\hline R17 & Kerusakan hardware & 2 & 1 \\
\hline $\mathrm{R} 18$ & Overheat & 2 & 1 \\
\hline R19 & Overload & 2 & 2 \\
\hline $\mathrm{R} 20$ & Kurang baiknya kualitas jaringan & 3 & 3 \\
\hline $\mathrm{R} 21$ & Listrik padam & 2 & 3 \\
\hline
\end{tabular}

\subsubsection{Risk Evaluation}

Proses terkahir untuk menyelesaikan tahap risk assesment adalah proses risk evaluation. Dalam proses ini menggunakan acuan berupa matrix evaluasi risiko. Diamana dalam matrix tersebut dibedakan ke dalam 3 risk level yaitu low, medium dan high. Kemungkinan risiko yang telah ditentukan nilai likelihood dan nilai impact pada proses sebelumnya akan dibedakan lagi menyesuaikan matrix yang ada. Tabel 7 telah memetakan risk level berdasarkan likelihood dan impact.

Tabel 7. Matrix evaluasi risiko

\begin{tabular}{|c|c|c|c|c|c|c|c|}
\hline \multirow{5}{*}{ 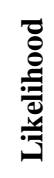 } & Certain & 5 & Medium & Medium & High & High & High \\
\hline & Likely & 4 & Medium & Medium & Medium & High & High \\
\hline & Possible & 3 & Low & Medium & & Medium & High \\
\hline & Unlikely & 2 & Low & Low & Medium & Medium & Medium \\
\hline & Rare & 1 & Low & Low & Low & Medium & Medium \\
\hline \multirow{2}{*}{\multicolumn{2}{|c|}{ Impact }} & & 1 & 2 & 3 & 4 & 5 \\
\hline & & & Insignificant & Minor & Moderate & Major & Catastrophic \\
\hline
\end{tabular}

Setiap kemungkinan risiko berdasrkan likelihood dan impact akan dimasukkan ke dalam matrix evaluasi risiko dengan melihat pemetaan pada tabel matrix evaluasi risiko sebelumnya. Di dalam tabel matrix evaluasi risiko identitas setiap kemungkinan risiko dimasukkan kedalam parameter yang sesuai dengan kriteria likelihood dan kriteria impact yang dilakukan sebelumnya.

Tabel 8. Matrix evaluasi risiko berdasarkan likelihood dan impact

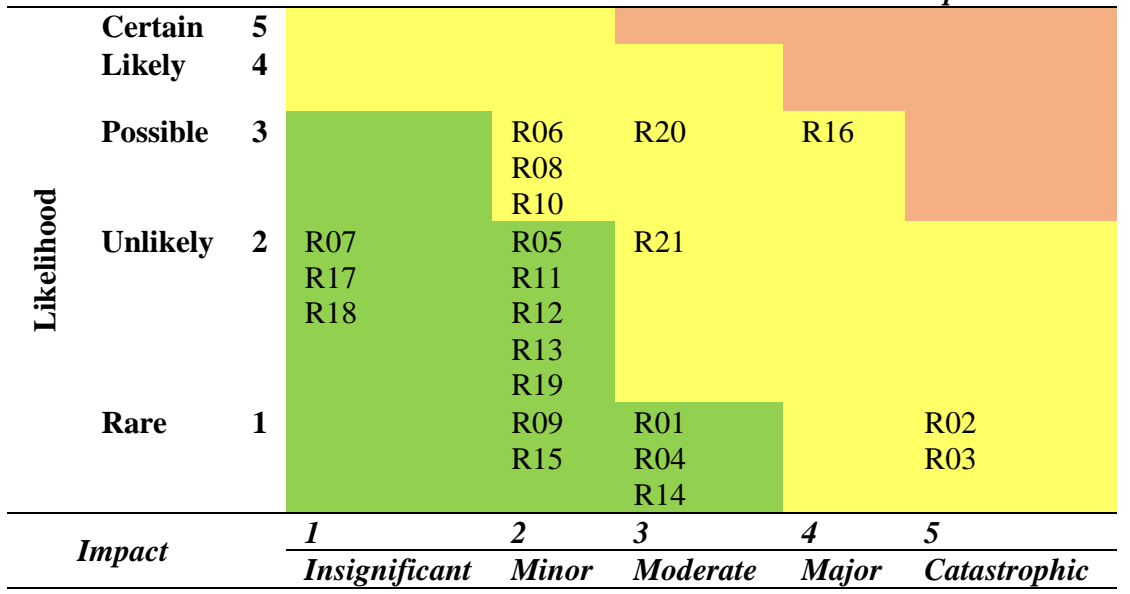

Kemudian setelah semua kemungkinan risiko yang ada dimasukkan ke dalam matrix evaluasi risiko pada tabel 9 akan dijabarkan dari 21 kemungkinan risiko yang ada termasuk kedalam level of risk dengan tingkatan high, medium atau low berdasarkan kriteria likelihood dan impact.

Tabel 9. Risk level dari kemungkinan risiko

\begin{tabular}{clccc}
\hline ID & \multicolumn{1}{c}{ Kemungkinan Risiko } & Likelihood & Impact & Risk Level \\
\hline R16 & Koneksi jaringan terputus & 3 & 4 & Medium \\
R20 & Kurang baiknya kualitas jaringan & 3 & 3 & Medium \\
R06 & Human Error & 3 & 2 & Medium \\
R08 & Data dan informasi tidak sesuai fakta & 3 & 2 & Medium \\
R10 & Server Down & 3 & 2 & Medium \\
R21 & Listrik padam & 2 & 3 & Medium \\
R02 & Gempa bumi & 1 & 5 & Medium \\
R03 & Kebakaran & 1 & 5 & Medium \\
R05 & Pencurian perangkat/data & 2 & 2 & Low \\
R11 & Data corrupt & 2 & 2 & Low \\
R12 & Backup failure & 2 & 2 & Low \\
R13 & Web service mati secara tiba-tiba & 2 & 2 & Low \\
R19 & Overload & 2 & 2 & Low \\
R07 & Informasi diakses oleh pihak yang tidak berwenang & 2 & 1 & Low \\
R17 & Kerusakan hardware & 2 & 1 & Low \\
R18 & Overheat & 2 & 1 & Low \\
\hline
\end{tabular}


Jurnal SITECH, Vol 2, No 1, Juni 2019

P-ISSN : 2615-8531, E-ISSN : 2622-2973

\begin{tabular}{|c|c|c|c|c|}
\hline$I D$ & Kemungkinan Risiko & Likelihood & Impact & Risk Level \\
\hline R01 & Banjir & 1 & 3 & Low \\
\hline R04 & Petir & 1 & 3 & Low \\
\hline R14 & Hacking terhadap jaringan & 1 & 3 & Low \\
\hline R09 & Kerusakan akibat ulah manusia (cybercrime dan vandalism) & 1 & 2 & Low \\
\hline R15 & Memori penuh & 1 & 2 & Low \\
\hline
\end{tabular}

Hasil dari proses risk evaluation dapat dilihat pada tabel 9 yaitu dari 21 kemungkinan terdapat 8 (koneksi jaringan terputus, kurang baiknya kualitas jaringan, human error, data dan informasi tidak sesuai fakta, server down, listrik padam, gempa bumi, kebakaran) yang termasuk kedalam level of risk tingkatan medium. Serta 13 (pencurian perangkat/data, data corrupt, backup failure, web service mati secara tiba-tiba, overload, informasi diakses oleh pihak yang tidak berwenang, kerusakan hardware, overheat, banjir, petir, hacking terhadap jaringan, risiko kerusakan akibat ulah manusia seperti cybercrime dan vandalism, memori penuh) yang termasuk kedalam level of risk tingkatan low.

\subsection{Risk Treatment}

Tahap setelah identifikasi risiko adalah tahap perlakuan risiko. Pada tahap ini, penulis akan memberikan saran-saran mengenai perlakuan untuk semua kemungkinan risiko yang ada pada aplikasi iTop. Saran perlakukan yang diberikan penulis diharapkan dapat mengurangi arau meminimalisr kemungkinan risiko yang ada. Serta dapat digunakan perusahaan untuk melakukan pencegahan terhadap kemungkinan risiko yang ada.

Tabel 10. Usulan tindakan risiko

\begin{tabular}{|c|c|c|c|}
\hline$I D$ & Kemungkinan Risiko & Risk Level & Tindakan Risiko \\
\hline R16 & Koneksi jaringan terputus & Medium & $\begin{array}{l}\text { Ketika koneksi jaringan terputus segera lapor ke bagian jaringan. } \\
\text { Melakukan maintenance jaringan di perusahaan secara berkala. }\end{array}$ \\
\hline $\mathrm{R} 20$ & $\begin{array}{l}\text { Kurang baiknya kualitas } \\
\text { jaringan }\end{array}$ & Medium & $\begin{array}{l}\text { Ketika koneksi jaringan menghambat perusahaan segera lapor ke } \\
\text { bagian jaringan. } \\
\text { Mengganti ISP (Internet Service Provider) jika jaringan yang } \\
\text { dipakai menggangu aktivitas peprusahaan. }\end{array}$ \\
\hline R06 & Human Error & Medium & $\begin{array}{l}\text { Melakukan pelatihan sebelumnya terhadap karyawan baru. } \\
\text { Membuat knowledge management system sebagai dokumentasi } \\
\text { pengetahuan bagi karyawan baru agar tidak melakukan kesalahan } \\
\text { yang sama. }\end{array}$ \\
\hline R08 & $\begin{array}{l}\text { Data dan informasi tidak } \\
\text { sesuai fakta }\end{array}$ & Medium & $\begin{array}{l}\text { Memastikan kembali data customer incident yang diterima sesuai } \\
\text { dengan fakta yang ada. }\end{array}$ \\
\hline $\mathrm{R} 10$ & Server Down & Medium & $\begin{array}{l}\text { Melakukan pengecekan secara berkala dalam } 1 \text { hari terhadap } \\
\text { database dari aplikasi iTop dan database utama perusahaan. } \\
\text { Melakukan refresh terhadap penggunan log, temp, dan RAM dari } \\
\text { aplikasi iTop dan database utama untuk mencegah server down. } \\
\text { Memasang antivirus yang terpercaya. }\end{array}$ \\
\hline R21 & Listrik padam & Medium & Menggunakan sumber listrik yang berbeda. \\
\hline R02 & Gempa bumi & Medium & $\begin{array}{l}\text { Memasang server cadangan di lokasi yang berbeda. } \\
\text { Melakukan mirroring database. }\end{array}$ \\
\hline $\mathrm{R} 03$ & Kebakaran & Medium & $\begin{array}{l}\text { Memasang server cadangan di lokasi yang berbeda. } \\
\text { Melakukan mirroring database. } \\
\text { Memasang fire hydran di dalam gedung perusahaan untuk } \\
\text { mencegah terjadinya kebakaran. } \\
\text { Menyediakan peralatan pemadam kebakaran di dalam gedung. }\end{array}$ \\
\hline R05 & Pencurian perangkat/data & Low & $\begin{array}{l}\text { Mengadakan maintenance password secara berkala. } \\
\text { Memasang CCTV di gedung perusahaan. }\end{array}$ \\
\hline R11 & Data corrupt & Low & $\begin{array}{l}\text { Melakukan backup data secara berkala. } \\
\text { Melakukan permbersihan pada PC secara berkala agar mencegah } \\
\text { munculnya virus/ malware. }\end{array}$ \\
\hline $\mathrm{R} 12$ & Backup failure & Low & $\begin{array}{l}\text { Memperhatikan penggunaan memori penyimpaan yang digunakan } \\
\text { secara berkala. } \\
\text { Melakukan backup data yang terdapat di aplikasi iTop dan } \\
\text { database utama secara berkala. } \\
\text { Membuat maintenance plan yang sesuai kebutuhan. }\end{array}$ \\
\hline $\mathrm{R} 13$ & $\begin{array}{l}\text { Web service mati secara } \\
\text { tiba-tiba }\end{array}$ & Low & $\begin{array}{l}\text { Segera melakukan perbaikan saat web service mati. } \\
\text { Memberikan pengumuman kepada customer. }\end{array}$ \\
\hline R19 & Overload & Low & $\begin{array}{l}\text { Melakukan pengecekan secara berkala terhadap database dari } \\
\text { aplikasi iTop dan database utama perusahaan. } \\
\text { Melakukan refresh terhadap penggunan log, temp, dan RAM dari } \\
\text { aplikasi iTop dan database utama sebelum server down. }\end{array}$ \\
\hline $\mathrm{R} 07$ & $\begin{array}{l}\text { Informasi diakses oleh } \\
\text { pihak yang tidak berwenang }\end{array}$ & Low & $\begin{array}{l}\text { Mengadakan maintenance password secara berkala. } \\
\text { Memasang CCTV di gedung perusahaan. }\end{array}$ \\
\hline
\end{tabular}




\begin{tabular}{|c|c|c|c|}
\hline$I D$ & Kemungkinan Risiko & Risk Level & Tindakan Risiko \\
\hline R17 & Kerusakan hardware & Low & $\begin{array}{l}\text { Membersihkan hardware setiap hari agar tidak berdebu. } \\
\text { Segera melaporkan kepada bagian teknisi jika ditemukan hardware } \\
\text { yang bermasalah. }\end{array}$ \\
\hline $\mathrm{R} 18$ & Overheat & Low & $\begin{array}{l}\text { Memastikan air conditioner sudah mampu membuat hardware } \\
\text { tetap dingin. }\end{array}$ \\
\hline R01 & Banjir & Low & $\begin{array}{l}\text { Memasang server cadangan di lokasi yang berbeda. } \\
\text { Melakukan mirroring database. }\end{array}$ \\
\hline R04 & Petir & Low & $\begin{array}{l}\text { Menyediakan tempat tinggi untuk menyimpan asset perusahaan. } \\
\text { Memasang server cadangan di tempat yang berbeda. } \\
\text { Melakukan mirroring database. } \\
\text { Memasang alat penangkal petir di gedung perusahaan. }\end{array}$ \\
\hline $\mathrm{R} 14$ & Hacking terhadap jaringan & Low & $\begin{array}{l}\text { Mengganti password server secara berkala. } \\
\text { Mengadakan maintenance jaringan secara berkala. }\end{array}$ \\
\hline R09 & $\begin{array}{l}\text { Kerusakan akibat ulah } \\
\text { manusia }(\text { cybercrime dan } \\
\text { vandalism })\end{array}$ & Low & $\begin{array}{l}\text { Mengganti password server secara berkala. } \\
\text { Memasang CCTV di gedung perusahaan. }\end{array}$ \\
\hline $\mathrm{R} 15$ & Memori penuh & Low & $\begin{array}{l}\text { Mengecek penggunaan memori ecara berkala. } \\
\text { Menambah kapasitas memori sebelum penuh. } \\
\text { Menghapus data-data perusahaan yang sudah lebih dari } 10 \text { tahun }\end{array}$ \\
\hline
\end{tabular}

\section{KESIMPULAN}

Tahapan analisis manajemen risiko pada aplikasi iTop di PT. ABCD yang berpedoman pada International Organization for Standardization (ISO 31000:2009) telah dilaksanakan. Proses analisis risiko yang dilaksanakan dari tahapan risk assesment yang melalui 3 langkah yaitu risk identification, risk analysis, dan risk evaluation. Dan tahap risk treatment untuk membuat saran-saran perlakukan risiko untuk kemungkinan risiko yang ada pada aplikasi iTop.

Dari hasil analisis risiko dapat dilihat, terdapat 21 kemungkinan risiko yang berpotensi menganggu kinerja aplikasi iTop. Terdapat 8 kemungkinan risiko yang termasuk kedalam level of risk tingkat medium, yaitu koneksi jaringan terputus, kurang baiknya kualitas jaringan, human error, data dan informasi tidak sesuai fakta, server down, listrik padam, gempa bumi, dan kebakaran. Serta terdapat 17 kemungkinan risiko yang termasuk kedalam level of risk tingkat low, yaitu pencurian perangkat/data, data corrupt, backup failure, web service mati secara tiba-tiba, overload, informasi diakses oleh pihak yang tidak berwenang, kerusakan hardware, overheat, banjir, petir, hacking terhadap jaringan, risiko kerusakan akibat ulah manusia seperti cybercrime dan vandalism, dan memori penuh.

Sebenarnya proses mengatasi risiko yang dilakukan oleh perusahaan sudah terlaksana, karena PT. ABCD merupakan perusahaan yang berfokus di bidang IT. Namun kemungkinan tidak dilaksanakannya pengangulangan risiko tersebut secara berkala dapat terjadi, sehingga diharapkan hasil penelitian ini dapat digunakan perusahaan untuk dapat menyusun kebijakan dan meminimalisir kemungkinan-kemungkinan risiko yang dapat terjadi pada perushaan dikemudian hari.

\section{DAFTAR PUSTAKA}

[1] N. Terry George Abisay, "Manajemen Risiko pada Bandara Soekarno Hatta Berbasis Iso 31000," pp. 116 129, 2013.

[2] D. D. J. Andi Novia Rilyani. Yanuar Firdaus, "Analisis Risiko Teknologi Informasi Berbasis Risk Management Menggunakan ISO 31000 (Studi Kasus : i-Gracias Telkom University)," e-Proceeding of Engineering, pp. 6201-6208, 2015.

[3] A. N. A. D. C. Stefan Agustinus, "Analisis Risiko Teknologi Informasi Menggunakan ISO 31000 pada Program HRMS," RESTI (Rekayasa Sistem dan Teknologi Informasi), pp. 250-258, 2017.

[4] R. V. I. Francisca Lady Nice, "Analisis Risiko Teknologi Informasi pada Lembaga Penerbangan dan Antariksa Nasional (LAPAN) pada Website SWIFTS Menggunakan ISO 31000," JUISI, pp. 1-11, 2016.

[5] "Risk management-Principles and guidelines," Standards Australia/Standards New Zealand, pp. 1-35, 2009.

[6] P. Zainal A. Hasibuan, "Metodologi Penelitian pada Bidang Ilmu Komputer dan Teknologi Informasi," pp. 1-194, 2007.

[7] R. A. K. Tri Ramdhany, "Analisis Risiko Sistem Informasi Penjualan Berbasis ISO 31000 - Risk Management di PT. Remaja Rosdakarya," pp. 1-7.

[8] D. J. P. K. A. S. S. Paulus Sukapto, "Integration of Risk Engineering by ISO 31000 and Safety Engineering: A Case Study in a Production Floor of Sport Footwear Industry in Indonesia," International Journal of Simulation, pp. 22.1-22.12, 2018.

[9] I. D. P. Angraini, "Analisa Pengelolaan Risiko Penerapan Teknologi Informasi Menggunakan ISO 31000," Jurnal Ilmiah Rekayasa dan Manajemen Sistem Informasi, pp. 70-76, 2017. 